GROSSMAN, David. Mel de leão: o mito de Sansão. Trad. Tova Sender. São Paulo: Companhia das Letras, 2006. 136p.

\title{
Mais doce que o mel, mais forte que um leão
}

\author{
Marcos Fábio de Faria*
}

Sansão pode ser considerado um dos mais notáveis e controversos personagens bíblicos, pois, nascido como nazireu de Deus e com um destino completamente traçado, ele se mantém, a todo instante, a contrapelo dos hábitos que esses homens sagrados deveriam seguir. Com uma força inigualável, que se concentrava em sua cabeleira, ele dilacera um leão e destrói exércitos. Muitos são as gerações de judeus que o conhecem por "Sansão, o herói" (p. 19). Sua aparição na Bíblia é breve, mas muito significativa, pois se encontra em um livro considerado histórico, Juízes. Nesse livro, Israel passa por um período de catorze Juízes acionados como libertadores do povo hebreu das mãos de seus inimigos. Publicado pela primeira vez em inglês no ano de 2006, mas escrito originalmente em hebraico, $\mathrm{Mel}$ de Leão: o mito de Sansão, de David Grossman, é apresentado ao público brasileiro nesse mesmo ano pela Companhia das Letras, com tradução de Tova Sender. é um belo ensaio filosófico e psicológico desse famoso herói para a cultura hebraica. Esse é o terceiro livro da série intitulada "Coleção mitos", em que renomados escritores, como Margaret Atwood e Karen Armstrong, foram convidados a tecer uma reflexão sobre os mitos que incitam o imaginário humano ao longo dos tempos.

A interpretação que o escritor faz do mito de Sansão cria uma investigação instigante e contemporânea da a trajetória desse ilustre personagem, contrariando diversas adaptações já realizadas do mito para o cinema e mesmo para a literatura. A leitura, que soa simples devido à leveza com que o tema é tratado, ganha projeção, e o que antes era só a narrativa de um herói, entre outros, passa a delinear e a forjar, pelas evocações de Grossman, um herói humanizado, complexo e poético. No texto, várias reflexões discorrem sobre o que o texto bíblico não soluciona, criando, assim, uma linha investigativa por parte do leitor. Assim, aquele que busca, pela Escritura, uma discussão dos pontos mais herméticos e obscuros da narrativa sobre esse herói, por exemplo, terá muitas surpresas. $\mathrm{Na}$ introdução, Grossman adianta, "A narrativa que leio nas páginas da minha bíblia, porém, é em certa medida a negação da história do famoso personagem Sansão" (p. 19).

O poder da letra ao planejar um enredo que não está escrito, mas que, quando imaginado, reverbera no leitor uma vontade de saber o que de fato nunca foi revelado, é o grande mote do livro. Imbuído de uma grande erudição e perspicácia, o escritor reflete sobre questões que podem passar despercebidas a muitos leitores. Como no estudo do Talmude, o texto bíblico é esmiuçado e atentamente entrecortado de cenas que não estão lá, mas que poderiam estar. A maestria com que o escritor imagina e questiona o relato pode ser inserida, também, como um elemento chave, ao longo da narrativa, entre os capítulos 13 e 16 de Juízes, são potencializados para o leitor em uma espécie de explicação literária.

Grossman cria, em sua exegese contemporânea, uma suspensão do heroísmo exacerbado de Sanção e discorre acerca dos pontos mais fracos da história, do homem. Assim, desde o milagre em que um filho é gerado por um casal estéril, até a narração de sua morte, acentua-se a difícil existência de um caminho já traçado e indissociável ao seu caráter de herói. Carregar essa dádiva que, pouco a pouco, se torna um fardo e um martírio é, em Mel de Leão, uma iluminação às contradições geradas por uma trajetória sem escolhas. Contraposta ao livre-arbítrio que todo homem possui, a vida de Sansão é apresentada como um sacrifício que se projeta em uma rebeldia, já estabelecida desde a promessa de vida, ser um nazireu. 
Uma das reflexões mais instigantes do livro diz respeito à relação que o personagem teria com o leão que estraçalhara. Esse ato corajoso, que foi ocultado de todos os homens que conhecia, ronda a história desse herói, e é nele que o personagem, segundo Grossman, se mostra poeta, criança e astuto. Grossman realiza, assim, uma surpreendente leitura de como o segredo desse duelo tornou-se um fardo a ser carregado por Sansão, pois a morte desse leão seria, para o escritor, a expressão máxima da força e do desconcerto de possuir outras virtudes que não ela. Em uma espécie de perseguição, o animal foi, ainda, a colmeia do mel que adoça a vida familiar do personagem, bem como da charada poética que encurrala os inimigos. "Do que come saiu comida, e do forte saiu doçura" (p. 68) - essa foi a charada, sem solução, que instiga e enlouquece os fariseus. O leitor, desse modo, é levado a crer que, em $\mathrm{Mel}$ de Leão, o único que estava preso em uma teia inquebrável sempre foi Sansão, pois já estava atado a ela desde o ventre de sua mãe.

Grossman apresenta, ainda, a fraqueza que o herói tinha por mulheres inimigas e, essa característica, inexplicável, para o escritor, cria uma lógica cerceada de profundidade: era esse um propósito de seu incontrolável destino? Mas, se assim era, por que isso deveria ser aceito? Assim, a discussão perpassa pontos tensos em que a parcela de desejo de que estava imbuído é questionada como existente de fato. Como a enigmática Dalila, um grande amor que o traiu, sua única amante a ser nomeada pela Bíblia, de quem não se sabe se era filistéia ou não, o certo é que ela foi peça fundamental no plano do qual Sansão não se safaria. Essa história é, nos relatos de Grossman, um das mais humanizadas, pois é quando a paixão o invade e a razão já não pode contê-lo, e ele, assim, entrega seu segredo à mulher amada, que o trai, entregando-o aos filisteus.

Traído e cego, Sansão é aprisionado e feito escravo pelos seus inimigos; depois, já com cabelos um pouco crescidos, é levado para ser exposto como troféu para milhares de filisteus. Arrependido, Sansão pede a Deus que se lembre dele. Recuperado da força, derruba, então, o templo sobre os milhares que o assistiriam. Tal passagem remete, em Mel de Leão, à densa e complicada trajetória desse juiz. Ao finalizar seu ensaio e marcar a complexidade do mito, Grossman afirma que até mesmo a traição fazia parte de um grande plano, e que Deus, de fato, nunca o havia esquecido. Com maestria, o escritor apresenta os dramas, os conflitos, tão humanos, da vida do herói.

* Marcos Fábio de Faria é Graduando em Letras e pesquisador do Núcleo de Estudos Judaicos da Universidade Federal de Minas Gerais. 